\title{
LJOURNAL.RU
}

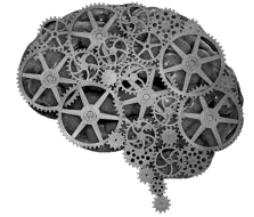

COMPANY GROUP "INTELLEKT"

\author{
Старожилов В.Т., Кудрявцев А,А \\ Дальневосточный федеральный университет \\ Владивосток, Россия
}

doi: 10.18411/lj2016-3-97

\section{Ландшафтная индикация химических изменений компонентов ландшафтов (на примере почв)}

На современном этапе развития ландшафтной географии Тихоокеанской России вопросы ландшафтной индикации химических изменений компонентов ландшафтов практически не решаются. Хотя, в связи с наметившимся на государственном уровне освоением территории, учету природных условий отводится значимое место. Работа включает результаты многолетних авторских научных и практических исследований в сфере геолого-географического изучения и ландшафтного картографирования крупных региональных Приморского, Сахалинского и др. звеньев окраинно-континентального ландшафтного пояса Тихоокеанской России [6]. Один из результатов исследований это получение данных для познания изменений компонентов ландшафтных геосистем на примере индикации почв.

Ландшафтное положение почв в ландшафтной геосистеме, взаимодействие, взаимообусловленность и взаимопроникновение друг в друга почвенного компонента с другими компонентами определяют качественные и количественные параметры ландшафтов. В свою очередь они обуславливают почвенный химический потенциал геосистемы и играют значимую роль в состоянии ландшафтных пространств, выделяемых в Приморье таксонов ландшафтов: местностей, видов, родов, подклассов, классов ландшафтов. Исследование химических ландшафтных особенностей почв, как компонента 
ландшафта, предпологает прежде всего установление ландшафтного статуса исследуемых изменений почв и отражение их в географических координатах на оцифрованных ландшафтных картах рассматриваемого географического пространства. В этом случае ландшафтные характеристики изменяющихся почв могут быть проанализированы в сравнении по выделам ландшафтов вплоть до регионального уровня на основе применения ландшафтного подхода.

В статье рассматриваются общие итоги регионального анализа, синтеза и оценка практической реализации ландшафтного подхода при изучении химических изменений почв. Использовались также опубликованные материалы $[4,5]$ и др.

\section{Ландшафтная индикация естественных химических изменений} компонентов в результате их загрязнения (на примере почв).

Состояние окружающей среды зависит от влияющих на неё природных и антропогенных факторов. К природным факторам относятся физикогеографические условия, обеспечивающие ее естественное состояние и фоновое содержание химических элементов в атмосфере, почве и водных акваториях и др. Антропогенное влияние на окружающую среду изменяет естественное состояние всех компонентов ландшафтной сферы. Технический прогресс на современном этапе связан с использованием природных ресурсов, развитием металлургической и химической промышленности, строительной и тепловой индустрии, развитием и увеличением количества различных видов транспорта.

В выбросах промышленных предприятий и транспорта содержится огромное количество различных химических веществ-загрязнителей. В тех случаях, когда предприятия нарушают экологические требования по очистке выбросов, происходит загрязнение окружающей среды (в том числе и почв) токсикантами промышленного происхождения. Вблизи промышленных предприятий и автострад формируется локальное загрязнение почв. оно на много превышает уровни естественного фонового содержания химических элементов и фонового загрязнения, характерного для почв промышленных 
центров. Загрязнение почв происходит и в сельскохозяйственном производстве, так как развитие земледелия невозможно без применения удобрений и средств защиты растений.

Техногенное загрязнение окружающей природной среды химическими веществами происходит следующими путями:

- промышленными выбросами загрязняющих веществ в атмосферу,

- сточными водами,

- через складирование и захоронение твердых отходов промышленного производства в почвах и водоемах. Попадая в ландшафты (воздух, водоемы, почву) загрязняющие вещества переносятся, распространяются воздушными потоками и водотоками, мигрируют из одного компонента в другую. Например, из воздуха в почву и водоемы, из почвы в водоемы и воздух, из водоемов в почву и воздушный бассейн. Наиболее активно и на большие расстояния загрязняющие примеси переносятся воздушными потоками, попадая на поверхность почв и водоемов в виде сухих и влажных выпадений. Химический состав сухих и влажных выпадений, то есть аэрозолей и атмосферных осадков зависит не только от локального загрязнения воздушного бассейна, характерного для данной местности, но и от миграции (перемещения воздушными потоками) загрязняющих примесей из других ландшафтных областей, провинций и округов. Количество минеральных веществ, выпадающих с осадками и аэрозолями, невелико и в сумме составляет всего несколько г/м ${ }^{2}$ в год. Но со временем происходит существенное обогащение почвенного покрова и водных бассейнов содержащимися в атмосферных сухих и влажных выпадениях веществами-загрязнителями. В результате миграции в ландшафтных геосистемах загрязняющие вещества проходят следующие стадии: разбавления, смешения, переноса, осаждения, выноса, рассеяния, образования новых веществ в результате химического взаимодействия. Процессы загрязнения завершается очищением ландшафта (или объекта): нейтрализация, разложение, ассимиляция загрязняющих веществ живыми организмами, накопление в локальной зоне, 
рассеяние или вынос в Мировой океан. Труднее всего происходит очищение от загрязняющих веществ почвенного покрова. Когда загрязнение почвенного покрова не завершается очищением, а наоборот, происходит накопление загрязняющих веществ, можно говорить о процессе частичной или полной деградации почв.

Рассмотрим на примере конкретных загрязнителей, как происходит химическое загрязнение почв ландшафтов в условиях юга Тихоокеанского окраинно-континентального ландшафтного пояса Тихоокеанской России..

Ландмафтная индикащия почв как поставщика элементов-загрязнителей в ландшафты бассейнов рек. Наиболее наглядно химические изменения почвенного покрова можно оценить по ландшафтам бассейнов рек. По результатам анализа, синтеза и оценке материалов среднемасштабного картографирования Приморского края отмечается, что в каждом водосборном бассейне из типов почв, развитых на изученной территории, наиболее распространены горные буро-таежные, бурые лесные, лугово-дерновые, луговые глеевые, лугово-торфяно-глеевые, торфяно-глеевые, аллювиальные.

В эрозионно-русловом процессе ландшафтов участвуют преимущественно почвы пойм, надпойменных террас и шлейфов пологих склонов. Поставщиком твердого почвенного материала, содержащего химические элементызагрязнители, являются в основном гумусово-аккумулятивные горизонты (мощность их может достигать от 5 до 35 см), подвергшиеся в той или иной степени антропогенной нагрузке. Этот материал в процессе эрозионноденудационных явлений перемещается с водными эрозионными потоками по поверхности водосборных бассейнов в русла рек, в озера и пруды, моря и океаны. Но в разных водосборных бассейнах антропогенная нагрузка на почвы и почвенный покров неодинакова. Так, Бортин Н.Н., Балябин В.Ф., Барышева Л.Г. и др [1]. объединили все бассейны рек изученной территории по загрязнению в несколько групп: 
1) водосборы с крайне высокой антропогенной нагрузкой, более чем в 100 раз превышающей допустимый уровень (ландшафты бассейнов оз. Ханка и рек южного Приморья), с круглогодичным загрязнением;

2) водосборы с высокой антропогенной нагрузкой, в десятки раз превышающей допустимый уровень загрязнения (ландшафты бассейнов рек Раздольной, Партизанской, Рудной, Шкотовки, Артемовки), где имеет место значительное очаговое загрязнение отдельных ландшафтов бассейнов (реки Рудная, Мельники, Дачная) при умеренном загрязнении большинства из них;

3) районы с умеренной антропогенной нагрузкой, не более чем в 2 раза превышающей допустимую нагрузку (ландшафты среднего течения Уссури, Арсеньевка, Зеркальная и рек Хасанского района), где сильное очаговое загрязнение приурочено к сосредоточенным выпускам сточных вод;

4) все оставшиеся ландшафты бассейнов рек, которым присуще значительное очаговое загрязнение только в маловодные периоды.

Ландшафтная индикаиия влияния на свойства и качество почвы ландшафтов токсикантов промышленного происхождения. Любой химический элемент в зависимости от геохимической, а точнее, от биохимической среды и природного объекта может быть и загрязнителем, и стимулятором роста. Здесь много зависит от концентрации химического элемента в ландшафте (почве, воде, горной породе и др.).

К веществам-загрязнителям ландшафтов техногенного происхождения относятся простые химические вещества и их неорганические и органические соединения. Степень загрязнения почв как компонента ландшафта теми или иными химическими веществами определяется относительно предельнодопустимых концентраций (ПДК) и ориентировочно-допустимых концентраций (ОДК), установленных для этих веществ. Степень загрязнения почв химическими веществами-загрязнителями, для которых ПДК и ОДК не установлены, оценивается по фоновому содержанию этих веществ в почвах, характерному для почв конкретного региона. 
Загрязнение почв ландшафтов элементами-загрязнителями шло и идет в основном вокруг крупных городов юга Тихоокеанского окраинноконтинентального ландшафтного пояса (Владивосток, Находка, Уссурийск, Артем, Спасск, Арсеньев, Кавалерово, Дальнегорск, Хабаровск). Основными источниками этих химических веществ-загрязнителей почв являются:

- машиностроительная и металлообрабатывающая промышленности во Владивостоке, Арсеньеве, Находке;

- судостроительная промышленность во Владивостоке, Славянке, Находке;

- стройиндустрия во Владивостоке, Уссурийске, Спасске, Лесозаводске, Новоникольске;

- железнодорожный транспорт с ремонтными базами в Уссурийске, Сибирцево, Смоляниново, Ружино;

- химическая и легкая промышленность во Владивостоке, Дальнегорске;

- горнорудная и горно-перерабатывающая промышленность в Артеме, Партизанске, Лучегорске, Ярославке, Кавалерово, Дальнегорске.

Основными транспортерами загрязнителей являются сточные воды и воздушные потоки из заводских труб. Жидкие стоки, несущие такие элементы, являются загрязнителями при длительном сбросе высококонцентрированных и плохо очищенных вод. Такие потоки обычно распространяются на небольшие расстояния от источника сброса, поэтому большого влияния на загрязнение почв не оказывают.

Особо следует сказать о техногенном влиянии на почвы горнорудной промышленности. В рассматриваемом регионе широко развита добыча полезных ископаемых и горючих материалов открытым способом. В виде каменноугольных разрезов, дражных полей, карьеров строительных материалов и сырья для химической промышленности (бариты, цеолиты и др.). При добыче минерального сырья открытым способом происходит тройное воздействие на почвы и почвенный покров: 
- разрушается почвенный покров в зоне функционирования горнорудного предприятия;

- отчуждаются площади почв под складирование вскрышных пород;

- возникают вторичные техногенные геохимические потоки, несущие химические элементы-загрязнители, вымытые из вскрышных пород.

Так, по данным Л.Т. Крупской [2], в Приморье Лучегорский каменноугольный разрез занял более 6 тыс. га пахотных земель, Павловский более 5, Липовецкий - более 3 тыс. га. Под вскрышные породы при этом ушло до 1,5 тыс. га пахотно-пригодных земель.

Как уже отмечалось, транспортерами и переносчиками химических элементов-загрязнителей являются сточные воды, вторичные техногенные геохимические потоки и выбросы заводских труб в атмосферу. Сточные воды, сбрасываемые разными предприятиями, имеют разный химический состав. Но все сточные воды содержат химические вещества, или химические элементы, которые в больших концентрациях могут оказывать угнетающее воздействие на биоту.

Эти геохимические потоки содержат высокие концентрации химических элементов, которые по пути транзита потока выпадают в осадок, загрязняя почвы и в целом ландшафт. Ведь такие потоки имеют много источников. Это вскрышные породы, бытовые свалки, хвостохранилища после переработки или обогащения горного сырья. География этих источников довольно обширна. Это все горнорудные предприятия, это крупные промышленные города, это карьеры стройиндустрии. Наиболее опасными источниками возникновения техногенных геохимических потоков являются вскрышные породы, складируемые в виде отвалов вокруг каменноугольных разрезов, дражных полей, рудников.

Активным транспортером химических элементов являются воздушные потоки. Хотя количество выпадений загрязняющих веществ на 1 м $^{2}$ исчисляется в граммах, воздушные потоки функционируют постоянно и привносят в почвы значительные количества химических элементов. Наиболее иллюстративным 
показателем этого являются данные об их содержании в почвах, расположенных на расстоянии 15 км от источника воздушного потока-загрязнителя.

Для примера приведем данные по городу Хабаровску [4]. В зоне влияния крупного источника загрязнения экосистем «ТЭЦ-3» изучено содержание тяжелых металлов в почвенном покрове. При этом установлено, что содержание кадмия на исследуемой территории в почвенном горизонте 0-20 см на расстоянии 1,5 км колеблется от 0.5 до 0.6 мг/кг, а на расстоянии 3 км составляет 0,3 мг/кг. Иная картина наблюдается в горизонте 21-40 см. На расстоянии 1,5 км его содержание, колеблется от 0,4 до 0,5 мг/кг, а на расстоянии 3 км от 0,1 до 0.2 мг/кг. Наибольшее накопление кадмия наблюдается в северо-восточном направлении 1,5 км зоны $(0,6$ мг

Содержание свинца в почве колеблется в пределах от 3,40 мг/кг до 8,80 мг/кг почвы. Наибольшая его концентрация наблюдается на расстоянии 1,5 км от источника в северо-восточном направлении, возможно, это связано с тем, что рядом с данной точкой отбора проходит автодорога.

В верхнем почвенном горизонте (0-20) см на расстоянии 1,5 км содержание свинца колеблется от 8,20 до 8,80 мг/кг, а на расстоянии 3 км колеблется от 5,10 до 6,10 мг/кг.

На расстоянии 1,5 км в почвенном горизонте 21-40 см его концентрация варьирует от 5,60 до 7,90 мг/кг почвы, а на расстоянии 3 км колеблется в приделах от 3,40 до 6,20 мг/кг. Наибольшее накопление свинца отмечается в зоне 1,5 км северо-восточного направления.

Максимальная концентрация никеля в почве (горизонт 0-20 см) на расстоянии 1,5 км от источника загрязнения составляет 35,00 мг/кг северовосточного направления. В горизонте 21-40 см на расстоянии 1,5 км содержание никеля колеблется от 21,10 до 17,00 мг/кг. На расстоянии 3 км в почвенном горизонте 0-20 см отмечается содержание никеля в пределах от 10,20 до 11,60 мг/кг, а в горизонте 21-40 см от 6,00 до 6,30 мг/кг. 
Содержание железа на исследуемой территории в почвенном горизонте 0 20 см на расстоянии 1,5 км колеблется от 9468,0 до 9821,0 мг/кг, а на расстоянии 3 км варьирует от 3446,0 до 8870,0 мг/кг. В почвенном горизонте 0-20 см на расстоянии 3 км его концентрация составляет 8870,0-3446,0 мг/кг и 1764,0 2964,0 мг/кг почвы в горизонте 21-40 см.

В целом установлено:

- наибольшее накопление тяжелых металлов в почве происходит в 1,5 км зоне СВ направления;

- наибольший процент загрязнения верхнего горизонта почвы отмечается для алюминия (69\%) и никеля (14\%). Наибольшая миграция вниз по почвенному профилю прослеживается у алюминия, никеля и свинца;

- превышение содержания никеля в почве CВ направления (1,5 км) составляет 8,75 ПДК , в 3 км зоне - 2,9 ПДК.

Изучение влияния Хабаровской ТЭЦ-3, как источника негативного воздействия на почвы и почвенный покров, позволяет выявить особенности распределения поллютантов в почвенном покрове и оценить степень накопления загрязнителей в промышленном объекте. Такие же исследования могут быть проведены на любом другом промышленном объекте на основе применения ландшафтного подхода, что нами доказано ранее на примере сопряжения горнорудного производства и ландшафтной географии [5].

В заключение отметим, что в итоге анализа, синтеза и оценки ландшафтного подхода при ландшафтной индикации химических изменений почв (компонента ландшафтов) можно утверждать, что на современном этапе ландшафтных исследований химические изменения почв проявляются во множестве типов, дифференцируются как специфические локальные территориальные образования, функционирование которых зависит от устойчивого равновесия всей системы «человек - общество - природа» и оптимизации природопользования. 
В результате анализа, синтеза и оценки ландшафтного подхода изучения химических изменений почв установлено, что химические изменения почв ландшафтов происходит во взаимосвязи, взаимообусловленности и взаимопроникновении друг в друга компонентов ландшафтов и уже наступило время когда химические изменения почв нужно изучать не оторвано от других компонентов, а на основе изучения межкомпонентных, межландшафтных связей с учетом межландшафтных, внутриландшафтных и внутрипочвенных почвенноэкологических, природопользовательских, природоохранных и других функций. Также можно констатировать, что уже можно применять ландшафтный подход к изучению локальных и региональных химических изменений почв ландшафтных геосистем географического регионального пространства Тихоокеанского окраинно-континентального ландшафтного пояса Тихоокеанской России.

Однако, так как ранее ландшафтный подход ландшафтной индикации изменений почв как компонента ландшафтов не применялся (отсутствовали оцифрованные региональные ландшафтные карты) то, прежде чем отмеченный подход применять нужно на оцифрованную региональную ландшафтную карту вынести все исследуемые разрезы почв с данными об их химических свойствах (на сегодняшний день такая опубликованная в открытой печати информация отсутствует) и установить ландшафтный статус изучаемых почвенных объектов. Только после выполнения отмеченного, можно приступать к анализу, синтезу и оценкам локальных и региональных ландшафтных химических изменений почв ландшафтного пространства не на общем, а на площадном количественном уровне с составлением соответствующих полимасштабных картографических материалов. Это важно для создания экологически благоприятных условий освоения и устойчивого развития Приморского края и географически сопряженных с ним территории Тихоокеанского окраинноконтинентального ландшафтного пояса. Важно также не только с точки зрения практической реализации ландшафтного подхода индикации изменения почв в 
ландшафтном пространстве, но и создания теории ландшафтной географии Тихоокеанской России и в целом ландшафтной сферы планеты Земля. 


\section{Литература:}

1. Бортин Н.Н., Балябин В.Ф., Барышева Л.Г. и др. Проблемы обеспечения населения Приморского края питьевой водой и пути их решения//Регилнальная целевая программа «Обеспечение населения Приморского края питьевой водой». - Владивосток: Дальнаука, 2000.- 388 c.

2. Крупская Л.Т. Охрана и рациональное использование земель на горных предприятиях Приамурья и Приморья. Хабаровск: ДВО РАН; Приамурское географическое общество, 1992. - 175с.

3. Старожилов В.Т. Особенности свойств почв в ландшафтных зонах затопления паводковыми водами (на примере Приморья): учебн. пособие / А.М. Дербенцева, В.И. Ознобихин, А.И. Степанова, В.Т. Старожилов, А.А. Бессарабова. - М.: ВНТИЦ, 2007. - № 50200700723. - 121 с.

4. Старожилов В.Т. Особенности химической деградации почв в ландшафтах юга Дальнего Востока: монография / Е.К. Папынов, А.М. Дербенцева, Л.П. Майорова, В.Г. Трегубова, В.Т. Старожилов, А.В. Назаркина, Т.И. Матвеенко, Л.Г. Пилипушка, В.Н. Пилипушка. - Владивосток: Изд-во Дальневост. ун-та, 2010. - 130 с.

5. Старожилов В.Т. Ландшафтная география Приморья (региональнокомпонентная специфика и пространственный анализ геосистем): монография / В.Т. Старожилов; [науч. ред. В.И. Булатов]. - Владивосток : Издательский дом Дальневост. федерал.ун-та, 2013. - 276 с.

6. Старожилов В.Т. Тихоокеанский окраинно-континентальный ландшафтный пояс как географическая елиница Тихоокеанской России и вопросы практики // Проблемы региональной экологии.- М.-. - 2013. - №5. - C. $1-7$. 